http://dx.doi.org/10.4314/jae.v18i2.12

\title{
Characteristics of Sesame (Sesamum indicum L.) Value Chain Development Programme in Bauchi State, Nigeria
}

\author{
Gizaki L. J. ${ }^{1}$, Madukwe M. C. ${ }^{2}$ \& Iwuchukwu J. C. ${ }^{2}$ Eze, S.O ${ }^{3}$ \\ ${ }^{1}$ College of Education P.M.B. 044, Azare, Bauchi State, Nigeria, \\ GSM = 08036945979, Email = ligizak@gmail.com. \\ ${ }^{2}$ Department of Agricultural Extension, University of Nigeria Nsukka, Enugu State, \\ Nigeria. \\ ${ }^{3}$ Department of Rural Sociology and Extension, Michael Okpara University of Agriculture, \\ Umudike, Abia State, Nigeria
}

\begin{abstract}
The study characterized Bauchi State sesame value chain development programme that started in April 2008 aimed at maximizing agricultural revenue through the production of sesame. Ninety respondents purposively and proportionately selected constituted the population for the study. The study revealed that the respondents on average produced $6.4990 \mathrm{~kg} / \mathrm{bag}$ of sesame and realized about $\mathrm{N} 86,000$ annually. The respondents perceived that the agencies have played most of the roles expected of them especially in supervising day to day activities of the demonstration farms $(M=3.64)$ and in establishment of demonstration farms $(M=3.55)$. Major constraints to the implementation of the programme as perceived by the respondents were marketing problems $(M=2.52)$ and lack of access to credit facility $(M=2.40)$. The study recommended that effort should be made to ensure that farmers get money for all seed produced and prevent exploitation of farmers by middle men.
\end{abstract}

Key words: Sesame, value chain, Bauchi State

\section{Introduction}

Sesame (Sesamum idicum L.) is a major export crop of Nigeria. Between 20072009, Nigeria was the third largest exporter of sesame in the world, exporting an annual average of more than 129,000 tons. Sesame seeds export value in Nigeria's merchandise trade increased remarkably in the fourth quarter of 2011 from 32.38 billion to 7.13 trillion, making it the highest ranking non-oil (agricultural) commodity contributor to the total exports during the quarter under review (USAID, 2011). It is grown in the following states: Adamawa, Bauchi, Benue, Borno, Cross River, Ebonyi, Gombe, Katsina, Kano, Kebbi, Kogi, Kwara, Niger, Plateau, Taraba, and Yobe with Nasarawa as the leading state (Adulugba, 2001).

The Bauchi state Sesame Value Chain programme (SVCP) started in April 2008 with the aim of maximizing agricultural revenue through the production of sesame in the state. In other to achieve this, Bauchi State Agricultural Development Programme (BSADP) entered an agreement with OLAM Nigeria and Maximizing Agricultural Revenue 
and Key Enterprise in Targeted Sites II (MARKETS II) on $31^{\text {st }}$ May 2012. Under the programme, BSADP will provide MARKETS II with mobilization, sensitization and registration of 4,000 farmers, $(50 \%$ of whom should be female and $30 \%$ of whom should be youth under 30 years) and continue to pay salaries and allowances of the extension agents (EAs) in Bauchi state. MARKETS II will on the other hand train BSADP EAs to strengthen their extension delivery capability and to mainstream a commodity value chain approach in its commodity development progamme while OLAM will make sesame seeds available to farmers and contribute 30\% refreshment and transport cost at training and field days. The expected results from this cooperation will among others include increase in farmers' productivity in sesame cultivation and heightened level of awareness in treating agriculture as a business (BSADP, 2012).

Sesame seeds (approximately $50 \%$ oil and $25 \%$ protein) are used in baking and in candy making while the oil can be used in manufacturing soaps, paints, perfumes, pharmaceuticals and insecticides. Sesame meal left after the oil is pressed from the seed is an excellent high-protein (34 to 50\%) feed for poultry and livestock (Oplinger, 1990). In Bauchi State, there are suitable agronomic conditions for growing sesame and existence of Sesame Value Chain programme (SVCP). These are opportunities for smallholder farmers in this area to participate in sesame production to enhance their income since sesame seed is an export potential cash crops (Lawan , 2011). Despite these available potentials and opportunities, majority of the smallholder farmers in the state are not participating in sesame production. Hence the need to characterize Sesame Value Chain programme (SVCP) in the state. Specifically the study ascertained output and income of the respondents their level of adoption of sesame technologies, their perception of accomplishment of expected roles by the agencies as well as constraints to the implementation of the programme in the state.

\section{Methodology}

\section{Population and Sampling techniques}

Beneficiaries of Bauchi State sesame value chain programme constituted the population for the study. A multistage sampling technique was employed to select the respondents. The first stage was to purposively select five (5) local government areas (LGAs) (Darazo, Giade, Ganjuwa, Gamawa and Katagum) from the 13 LGAs that participated in the programme. Registered respondentss as revealed by BSADP were Darazo (274), Giade (318), Ganjuwa (437), Gamawa (460) and Katagum (225). Proportionate sampling technique was used to select $6 \%$ of the registered respondents in each LGA, giving a total of 101 respondents. However, 90 respondents were located during field work and eventually participated in the study.

\section{Data Collection}

Data were collected through the use of structured interview schedule. Respondents were asked to state the quantity (number of $90 \mathrm{~kg}$ bags produced) of sesame produced and income realized from selling them.

The adoption levels of the various innovations introduced to the sesame farmers was measured on a 5-point Likert-type scale. For each of the practices itemized in the 
interview schedule, the farmers were asked to indicate their adoption stage on the 5-point adoption scale (aware $=1$, interest $=2$, evaluation $=3$, trail $=4$, adoption $=5$ ). Other adoption characteristics were calculated as follows:

- Computation of total adoption score per innovation. This was by adding up all the various adoption scores for each innovation.

- Computation of total mean (M) adoption score per innovation. This was by computing the total adoption score and dividing it by the number of respondents involved.

- Computation of the grand mean (M) adoption score. This was calculated by adding all the total mean adoption scores and dividing them by the number of innovations considered.

- Computation of adoption index. This was carried out by dividing the grand mean (M) adoption score by 5 (i.e. the 5 -stages of adoption).

A list of expected roles of the agency involved in the implementation of the programme in the area was provided for the sesame farmers to tick on the extent the agency has accomplished these roles. These data were generated using 4 - point Likert type scale of to a very great extent $=4$, great extent $=3$, to some extent, $=2$ and to no extent $=1$.

Respondents were also requested to indicate the extent they perceive list of possible factors as constraints to implementation of the programme on a 3 point Likerttype scale of very serious $=3$, serious $=2$ and not serious $=1$. Opportunity was also provided for them to list other constraints that are not in the list. Data analysis

Data were analysed with percentage and mean statistics.

\section{Results and discussion}

\section{Annual output and income realized from sesame}

Entries in Table 1 indicate that greater proportion $(47.7 \%)$ of the respondents harvested 1 to5 bags of sesame seed while $34.4 \%$ harvested 6 to 10 bags of sesame seeds per hectare annually. The mean annual output was 6.49 bags of sesame seed.

Table 1 also revealed that $30 \%$ of the respondents realized $\mathbb{N} 400,0001$ to $\mathbb{N}$ 500,000 in a year, 20\% realized $\$ 200,001$ to $\$ 300000$, while $17.7 \%$ realized an annual income of $\$ 500.001$ to $\$ 600,000$ from the sales of sesame seeds. Their mean annual income from sesame seed was $\$ 85,986.67$. This may imply that sesame production is an income yielding venture that should be encouraged in the state. The finding corroborates the fact that sesame production in Jigawa state was profitable (Makama, Murtala and Abdu, 2011) 
Table 1: Estimates of output ( $90 \mathrm{~kg} / \mathrm{bag}$ ) and income (N) from sesame seed

\begin{tabular}{lll}
\hline Income (A) & Percentage $(\mathrm{n}=90)$ & Mean \\
\hline$<100000$ & 14.4 & 85986.67 \\
$100,001-200,000$ & 5.5 & \\
$200,001-300,000$ & 20 & \\
$300,001-400,000$ & 10 & \\
$400,001-500,000$ & 30 & \\
$500,001-600,000$ & 17.7 & \\
Above 600,000 & 3.3 & \\
Quantity of 90 & \\
kg/bag of sesame & & \\
seed & 47.7 & \\
$1-5$ & 34.4 & \\
$6-10$ & 17.7 & \\
$11-15$ & 2012
\end{tabular}

Source: Field survey, 2012.

\section{Adoption of sesame recommended practices by the respondents}

Table 2 reveals that the farmers had adopted all the recommended practices / technologies of sesame production except diseases and pest control (2.79) and harrowing $(M=2.2)$. Specifically, ploughing with hoe $(M=4.23)$, using animal drawn ploughs $(M=4.16)$, ploughing after the first rain $(M=4.15)$, selection of fairly flat and well drained land $(M=3.79)$, and use of tractors $(M=3.66)$ were technologies related to preplanting operations that the respondents adopted. Some of these methods of land clearing adopted by the respondents are strenuous. Elsewhere, in East Wollega, Ethiopia, it was reported that over 92 percent of the sampled farmers depend on oxen for sesame cultivation and the rest depends on hoe (Gobena, 2012) .

Table 2 also reveals that technologies on planting operations adopted by the respondents were manual weed control $(M=4.60)$, planting from late June to first week of July $(M=4.23)$, using seeds of the same type and variety $(M=4.03)$, using clean and healthy seeds ( $M=4.01)$, using improved varieties $(M=3.78)$, maintaining plant spacing of $15 \mathrm{~cm}$ apart on ridge $(M=3.59)$, application of fertilizer $(\mathrm{M}=3.45)$, maintaining plant spacing of $60 \mathrm{~cm}$ apart on flat bed $(M=3.38)$ and use of herbicides $(M=3.04)$. It has been reported 
that low production and productivity of sesame is mainly associated with poor adoption of improved varieties (Umar, Lawal and Oboh, 2010)..

Post planting technologies adopted by the respondents were storing sesame seed in a clean and roofed store $(M=4.81)$, harvesting using sickle or knife $(M=4.72)$, avoidance of uprooting during harvesting to avoid contamination $(\mathrm{M}=4.63)$, harvesting as soon as the crops matures ( from October to December) $(\mathrm{M}=4.57)$, Harvesting after $90-130$ days when many leaves have dropped off and most of the remaining ones have turned yellow $(\mathrm{M}=4.51)$ and threshing of sesame seed using tarpaulin $(\mathrm{M}=4.47)$. The study has revealed that the respondents adopted all the post planting technologies.

The adoption index (0.73) and grand mean (3.84) were high, implying that generally, these farmers have adopted most of the innovations on sesame disseminated to them. 
Table 2: Distribution of respondents on their adoption of recommended practices

Recommended practices

A. Pre-planting operations

Selection of land that is fairly flat and well drained

Ploughing with hoe

Using animal drawn plough

Using tractor

Ploughing after the first rain

Harrowing

\section{B. Planting operations}

using improved varieties

Using clean and healthy seeds

Choosing seeds of the same type and variety

Planting Late June to first week of July

Plant spacing of $60 \mathrm{~cm}$ apart on flat bed

Plant spacing of $15 \mathrm{~cm}$ apart on ridges

Fertilizer application

Manual weed control 4.60

Use of herbicides

Disease and pest control

\section{Post-planting operations}

- Harvest after 90 - 130 days when many leaves have dropped off and most of the remaining ones have turned yellow

- Harvest as soon as the crop matures from late October to 4.57 December

- Do not harvest by uprooting to avoid contamination

- Harvest using sickle or knife

- Threshing of sesame seed using tarpaulin

- Store in a clean and roofed store

Source: Field survey 2012. 


\section{Farmers' Perceptions of the Roles Played by the Agencies Involved in Implementation of the Programme}

Data in Table 3 reveal that the respondents perceived that the agencies had played most of the roles expected of them, as most of the roles scored more than the mean of 2.5. Prominent among them are supervision of day to day activities of the demonstration farms $(M=3.64)$, establishment of demonstration farms $(M=3.55)$, extension visits to farmers $(M=3.53)$, registration of 4000 farmers $(50 \%$ females and $30 \%$ youth under 30 years) $(M=3.45)$, providing technical assistance $(M=3.37)$, organizing field days, preseason and post - season harvest and cross - cutting trainings to the out-growers ( $M=$ 3.29), making sesame seeds available to farmers $(M=3.20)$, providing handbooks to the out-growers to improve their understanding of the use and application of agricultural best practices $(M=3.15)$ and assistance in timely application of fertilizers $(M=3.04)$. The essence of demonstration plots is for the farmers to see difference. Demonstrating improved farming techniques that showcase high yield helps farmers to produce high quality sesame seed for commercial processing (Abara and Singh, 1993)

Contribution of $30 \%$ refreshment and transport costs at training and field days ( $M=2.77)$, linking farmers and other stake holders to commercial banks $(\mathrm{M}=2.37)$ and buying all sesame produced $(M=2.03)$ were roles the agencies did not play well. Thus acquisition of inputs and other operations in the farm that need money may be difficult for these farmers due to inadequate funds. This agrees with the findings of Abu, Onyibe, and Tologbonse, (2012) that inadequate fund or capital was the most commonly expressed problem of sesame production by the farmers in Nasarawa state. 
Table 3: Mean ratings of farmers' perception of the roles played by the agencies involved in implementation of the programme.

Agencies

Mean Std.

deviation

BSADP (roles)

- Register 4000 farmers 50\% female and 30\% youth under $30 \quad 3.45$ years

- Extension visit to farmers

- Providing technical assistance

- Supplying input/credits and equipment to out-grower

- Establishment of demonstration farms

- Supervising day to today activities of the demonstration farms

- Involving sesame farmers in decision - making

- Assistance in timely application of fertilizers

- OLAM (roles)

- Making sesame seeds available to farmers

- Buying all sesame produced

- Contribute $30 \%$ refreshment and transport costs at training and field days

- Providing handbooks to the out - growers to improve their understanding of the use and application agricultural best practices

- Organizing field days, pre-season and post - season harvest and cross - cutting trainings to the out-growers

$\begin{array}{llll}\text { - Linking farmers and other stake holders to commercial } & 2.37 & 1.19\end{array}$ banks

Source: Field survey 2012

\section{Constraints to the Implementation of the Programme}

Major constraints to the implementation of the programme as perceived by the respondents were marketing problems $(M=2.52)$, lack of access to credit facility $(M=$ $2.40)$, inability to access government assistance $(M=2.36)$, untimely supply of farm inputs and cash loans $(\mathrm{M}=2.35)$ poverty among farmers $(\mathrm{M}=2.29)$ (Table 4). Other serious constraints to the implementation of the programme included high risks and uncertainty in agriculture $(M=2.19)$, high cost of farm input $(M=2.16)$, poor storage facilities $(M=2.15)$, low price of sesame seed $(M=2.11)$ and disease and pest infestation $(M=2.07)$. Some of these constraints were reported in Nasarawa State. (Umar, 2010) . 
However, unavailability of agro chemical and other farm equipment $(M=1.87)$, low productivity/yeild from sesame $(M=1.84)$, high cost of improved sesame seed for planting ( $M=1.83)$, high cost of agro chemical $(M=1.81)$, insufficient land $(M=1.69)$, were not considered as constraints. This is expected as the programmes provided the facilities to the farmers.

Table 4: Mean of constraints to the implementation of the programme

\begin{tabular}{lll}
\hline Constraints & Mean (M) & Std. Deviation \\
\hline High cost of farm input & 2.16 & 0.698 \\
- $\quad$ Lack of sufficient land & 1.69 & 0.735 \\
- $\quad$ High cost of agro-chemicals & 1.81 & 0.817 \\
- $\quad$ Poor extension agent -farmer contact & 1.68 & 0.701 \\
- $\quad$ Poor access roads to farmers plot & 1.80 & 0.717 \\
$\quad$ Poor storage facilities & 2.15 & 0.806 \\
- $\quad$ Lack of access to credit facility & 2.40 & 0.697 \\
- $\quad$ Instability of government policy & 2.25 & 0.718 \\
- $\quad$ Poverty among farmers & 2.29 & 0.712 \\
- Inability to access government assistance & 2.36 & 0.751 \\
- High risks and uncertainty in agriculture & 2.19 & 0.711 \\
- $\quad$ Climate change & 2.28 & 0.605 \\
- Marketing problems & 2.52 & 0.603 \\
- Unavailability of agro - chemicals and other farm & 1.87 & 0.759 \\
- $\quad$ Low price of the sesame seed & 2.11 & 0.689 \\
- $\quad$ Disease and pest infestation of sesame & 2.07 & 0.794 \\
- Untimely supply of farm inputs and cash loans & 2.35 & 0.688
\end{tabular}

\section{Source: Field survey 2012}

\section{Conclusion}

The sesame value chain development programme in Bauchi State is characterized by good performance of the implementing agencies, high adoption rates, lack of access to credit and markets.

\section{Recommendations}

1. There is need for infrastructural development especially in construction/building of good/standard market for easy delivery of goods produced to other buyers and users. 
Government should also enact and implement favourable policy that will ensure that all seed produced are purchased directly by the government probably through agencies responsible for the programme at reasonable price to avoid exploitation of the farmers by the brokers (middle men ) especially when there is glut in the market.

2. Agencies charged with the responsibility of implementing this programme should link farmers and other stake holders to commercial banks to source loan and boost their production

3. Extension agents should train the sesame farmers on appropriate diseases and pests control measures.

\section{References}

Abara, I. O. C. and S.Singh, (1993). Ethics and biases in technology adoption: The small farm argument. Technologies forecasting and social change, 43, 289-300.

Abu, S. S., Onyibe, J. E., and Tologbonshein, E. B. (2012). The role of extension research and information dissemination in enhancing beniseed production, marketing of resource poor farmers. Proceeding of the First Workshop on Beniseed, held at the National cereal research institute, Badegi, Nigeria, March $3^{\text {rd }}$ $-5^{\text {th }}$ 1998. pp. 86-9.

Adulugba, A. A. (2001). Growth and development of the Nigerian non-oil sector: Key to successful economic diversification. A presentation at the $51 \mathrm{AGM} /$ Conference of NACCIMA held in Abuja, Nigeria on $10^{\text {th }}$ September, 2001.

Bauchi state Agricultural Development Programme (BSADP) (2011). Bauchi farmers target 50,000 tons of sesame seed. Available at http://www.feelfree.co/article_news/nigeria/?p9.

Bauchi state Agricultural Development Programme (BSADP) (2012): 2000 Bauchi farmers get free sesame seeds. Blueprint (2012). Available at http://printing.com/new/2012/07/2000-bau. 17/06/2013.

Gobena, G. K. (2012). Analysis of small holder farmer's participation in production and marketing of export potential crops: The case of sesame in Diga district, east Wollega zone of Oromia regional state, Ethiopia. A thesis submitted to the school of economics in partial fulfillment of the requirements for the degree of masters of science (International Economics), p. 47.

Lawan, S. (2011). Revolutionizing agriculture through sesame production in Bauchi state. Available at http://ng.Linkedin.com/pub/lawanshirama/41/243. Assessed, 20/06/12.

Makama, S. A. N., Murtala and Z. Abdu, (2011).Economic analysis of sesame production in Taura Local Government Area, Jigawa State, Nigeria. Savanna Journal of Agriculture 6(2), pp. 6-12. 
Oplinger, E. S. (1990). ACA for corn. Wisconsin fertilizer, Ag lime, and pest management conference proceedings. Madison, WI. 29: 38-42. Available at http://www.extension.umn.edu/distribution/cro. 17/06/13

Umar, A. B., W. L. Lawal and V. U. Oboh (2010). Agricultural productivity and poverty alleviation issues: The Nigerian perspectives. Online at http://dl.nsf.ac./k/bitstream/1/8187/2/TARE-9-27.p. Assessed 14/06/13.

USAID (2011). Sesame square Nigeria USAID/Nigeria. Available at https://www.go. 